\title{
A New Anti-Platelet Drug, E5510, Has Multiple Suppressive Sites during Receptor-Mediated Signal Transduction in Human Platelets
}

\author{
Tohru Fujimori, Koukichi Harada, Takao Saeki, Motoji Kogushi, \\ Tsutomu Yoshimura and Kouichi Katayama \\ Eisai Research Laboratories of Tsukuba, Eisai Co., Ltd., 5.I-3 Tohkodai, Tsukuba, lbaraki 300-26, Japan \\ Received September 4, I990 Accepted October 11,1990
}

\begin{abstract}
The mode of action of E5510, 4-cyano-5,5-bis(4-methoxyphenyl)-4-pentenoic acid, which has very potent anti-platelet activities, was investigated by examining its effects on the biochemical responses in the process of human platelet activation. In a whole-cell system, E5510 inhibited the increased tumover of inositol phospholipids arising from phospholipase $\mathrm{C}$ activation, arachidonic acid release from phospholipids by phospholipase $\mathrm{A}_{2}$, mobilization of intracellular free $\mathrm{Ca}^{2+}$, protein kinase $C$ activation, and thromboxane $A_{2}$ production. In a cell-free system, E5510 inhibited cyclooxygenase activity and cyclic AMP-dependent phosphodiesterase activity in a dose-dependent manner. An elevation of cyclic AMP in platelets was also observed at a relatively high concentration of E5510. It was suggested that receptor-mediated turnover of inositol phospholipids, intracellular $\mathrm{Ca}^{2+}$ increase, arachidonic acid release from phospholipids and protein kinase $\mathrm{C}$ activation might be indirectly inhibited by the increased cyclic AMP level in platelets. Thromboxane $\mathrm{A}_{2}$ production in the whole-cell system was very strongly inhibited by $\mathrm{E} 5510$, and the $\mathrm{IC}_{50}$ for this effect was 100 times lower than that of direct inhibition of cyclooxygenase in the cell-free system. It was concluded that although the primary mode of action of E5510 is the inhibition of the cyclooxygenase pathway of positive signal transduction in platelets, E5510 has another mode of action by increasing platelet cyclic AMP, which can act as a negative messenger in platelet signal transduction, and these multiple sites of action synergistically antagonize platelet cellular activation.
\end{abstract}

E5510, 4-cyano-5,5-bis(4-methoxyphenyl)-4pentenoic acid, is a very powerful platelet aggregation inhibitor (1). This compound strongly inhibits human platelet aggregation induced by collagen, ADP, epinephrine, platelet-activating factor, AA or thrombin in vitro. This inhibitory action is similar in some respects to that of CO inhibitors such as ASA and $\mathrm{U} 53059(2,3)$, in terms of the preferential suppression of secondary platelet aggregation. However, there exists an absolute difference between $\mathrm{E5510}$ and $\mathrm{CO}$ inhibitors in that

\footnotetext{
Abbreviations used are: ADP, adenosine 5'-diphosphate; AA, arachidonic acid; CO, cyclooxygenase; ASA, acetylsalicylic acid; PI turnover, turnover of inositol phospholipids; PLC, phospholipase C; PA, phosphatidic acid; $\mathrm{IP}_{3}$, inositol trisphosphate; PKC, protein kinase C; PLA $\mathbf{A}_{2}$, phospholipase $\mathrm{A}_{2} ; \mathrm{TX}$, thromboxane; BSA, bovine serum albumin; PRP, platelet-rich plasma; 12-HETE, 12-hydroxy-5,8,10,14-eicosatetraenoic acid; HHT, 12hydroxy-5,8,10-heptadecatrienoic acid; SDS, sodium dodecyl sulfate; PDE, phosphodiesterase; SSVM, sheep seminal vesicular microsomes.
} 
E5510 dose-dependently inhibits thrombininduced platelet aggregation, which is not inhibited by $\mathrm{CO}$ inhibitors (1). The mode of action of this compound against platelet activation has not yet been clearly established.

Biochemical events in platelets respond to both positive and negative signals $(4,5)$. In short, extracellular positive signals which bind to specific receptors on the platelet membrane promote the PI tumover through activation of PLC, which results in rapid production of diacylglycerol and inositol phosphates (6-8). As diacylglycerol is readily converted to PA, an increase in PA is observed after platelet activation (9). $\mathrm{IP}_{3}$ and diacylglycerol, intermediates of PI turnover, induce intracellular $\mathrm{Ca}^{2+}$ mobilization $(10,11)$ and $\mathrm{PKC}$ activation (12), respectively. The intracellular $\mathrm{Ca}^{2+}$ increase promotes the release of AA from platelet phospholipids through activation of PLA $_{2}$ (13). The released AA is converted into $\mathrm{TXA}_{2}$ which can act as a feedback promoter and induce further stimulation of PLC, leading to acceleration and amplification of platelet activation. TXA $\mathrm{A}_{2}$ acts as a powerful positive signal for non-activated platelets (14). On the contrary, negative signals such as $\mathrm{PGI}_{2}$ activate platelet adenylate cyclase and increase cyclic AMP content in the platelets. This increase in cyclic AMP inhibits the receptorlinked degradation of inositol phospholipids and the $\mathrm{Ca}^{2+}$ mobilization, which result in activation of PLA $\mathrm{A}_{2}$ and PKC during activation of platelets by the positive signals, and suppresses the cellular response of platelets (12, 15).

The purpose of this paper is to elucidate the mode of action of E5510 in inhibiting receptor-mediated platelet activation. We studied the effects of this compound on positive signal transduction and negative signal transduction in human platelets.

\section{MATERIALS AND METHODS}

\section{Materials}

E5510, U53059, OPC13013 (Cilostazol) and BW755C were synthesized in our laboratory.
ASA, mepacrine (quinacrine $2 \mathrm{HCl}$ ) and $\mathrm{PGE}_{1}$ were purchased from Iwaki Pharmaceutical (Tokyo, Japan), Sigma (St. Louis, U.S.A.) and Funakoshi Pharmaceutical Co., Ltd. (Tokyo Japan). Drugs were dissolved in dimethyl sulfoxide and diluted to the desired concentration with saline containing $0.1 \%$ BSA. Fura2/AM was from Molecular Probes (Junction City, U.S.A.). $\left[1-{ }^{14} \mathrm{C}\right]$ Arachidonic acid $(54.9 \mathrm{mCi} / \mathrm{mmol}),{ }^{32} \mathrm{P} \mathrm{Na}_{2} \mathrm{HPO}_{4} \quad(0.9-$ $1.1 \mathrm{Ci} / \mathrm{mmol})$ and $\left[2,8-{ }^{3} \mathrm{H}\right]$ adenosine $3,5^{\prime}$-cyclic phosphate $(32.1 \mathrm{Ci} / \mathrm{mmol})$ were purchased from NEN (Boston, U.S.A.). Thrombin from bovine plasma $(77 \mathrm{U} / \mathrm{mg})$ was obtained from Miles Lab. (Elkhart, U.S.A.). All other reagents used here were analytical grade.

\section{Preparation of human platelets and aggregation measurement}

Human venous blood of healthy male volunteers who had not received any medication for more than two weeks was anti-coagulated with one-tenth volume of $3.8 \%$ sodium citrate and centrifuged at $100 \times g$ for $10 \mathrm{~min}$ at room temperature to obtain PRP was washed twice with $0.1 \%$ EDTA saline and finally suspended in $\mathrm{Ca}^{2+}$-free Tyrode solution containing $0.1 \%$ BSA at the cell concentration of $5 \times 10^{8}$ cells $/ \mathrm{ml}$. Silicon-coated glassware or polypropylene tubing was used for preparing PRP and in the following experiments.

Platelet aggregation was measured according to Born's turbidimetric method (16) with an aggregometer (Hematracer, Nicho Bioscience Co., Ltd., Tokyo, Japan), after preincubation of a $200-\mu \mathrm{l}$ aliquot of washed platelets and 25 $\mu \mathrm{l}$ of drug solution for $3 \mathrm{~min}$ at $37^{\circ} \mathrm{C}$. To induce platelet aggregation, $25 \mu \mathrm{l}$ of thrombin dissolved in Tyrode solution was added to the reaction mixture. The intensity of platelet aggregation was measured according to the method reported previously (1), and the effects of test drugs were expressed as \% inhibition values compared to the control.

Preparation of radioisotope-labeled platelets

$\left[1-{ }^{14} \mathrm{C}\right] \mathrm{AA}$ was added to PRP to give the concentration of $1.7 \mu \mathrm{Ci} / \mathrm{ml} \mathrm{PRP}$, and the 
mixture was incubated at $37^{\circ} \mathrm{C}$ for $1 \mathrm{hr}$. The platelets were washed twice with $15 \mathrm{mM}$ Trisbuffered saline (pH 7.4) containing $5 \mathrm{mM}$ $\mathrm{KCl}, 1 \mathrm{mM}$ EGTA, and $5.5 \mathrm{mM}$ glucose and finally suspended in the same buffer without EGTA to give the cell concentratiion of $3 \times$ $10^{8}$ platelets $/ \mathrm{ml}$.

${ }^{32}$ P-Prelabeled platelets were obtained by incubating platelets with $15 \mathrm{mM}$ Tris buffer (pH 7.4) containing $129 \mathrm{mM} \mathrm{NaCl}, 2.8 \mathrm{mM}$ $\mathrm{KCl}, 1 \mathrm{mg} / \mathrm{ml}$ glucose, $8.9 \mathrm{mM} \mathrm{NaHCO} 3$ and $1.1 \mathrm{mCi}\left[{ }^{32} \mathrm{P}\right]-\mathrm{Na}_{2} \mathrm{HPO}_{4}$ at $37^{\circ} \mathrm{C}$ for $30 \mathrm{~min}$ and then suspending them in $15 \mathrm{mM}$ Tris buffer (pH 7.4) containing $135 \mathrm{mM} \mathrm{NaCl}, 5 \mathrm{mM}$ $\mathrm{KCL}$ and $5.5 \mathrm{mM}$ glucose at the cell concentration of $4 \times 10^{8}$ platelets $/ \mathrm{ml}(17)$.

Determination of $A A$ release ( $P L A_{2}$ activity) in thrombin-stimulated platelets

A mixture of $0.8 \mathrm{ml}$ of $\left[{ }^{14} \mathrm{C}\right] \mathrm{AA}$-labeled platelet suspension, $0.1 \mathrm{ml}$ of drug solution or vehicle and $0.05 \mathrm{ml}$ of $20 \mathrm{mM} \mathrm{CaCl}_{2}$ was preincubated at $37^{\circ} \mathrm{C}$ for $3 \mathrm{~min}$ in the presence of $100 \mu \mathrm{M}$ BW755C, which completely inhibited both $\mathrm{CO}$ and lipoxygenase (18), and the platelets were activated by adding $0.05 \mathrm{ml}$ of 1 $\mathrm{U} / \mathrm{ml}$ thrombin. After $3 \mathrm{~min}$, the reaction was terminated by the addition of $0.1 \mathrm{ml}$ of icecold $0.1 \mathrm{~N} \mathrm{HCl}$. Lipids were extracted into 4 $\mathrm{ml}$ of chloroform : methanol (2:1) according to the method of Bligh and Dyer (19). ${ }^{14} \mathrm{C}$ Labeled eicosanoids were separated by thin layer chromatography on a silica gel plate (Whatman, LK6-DF, Clifton, U.S.A.) in a solvent system consisting of the organic phase from ethyl acetate/2,2,4-trimethylpentane/acetic acid/water (110:50:20:100) (20). The areas corresponding to AA, 12-HETE, TXB $_{2}$ and HHT were scraped off and the radioactivities were measured. The increase in the sum of the radioactivities in AA, 12-HETE, TXA and HHT was considered to reflect the PLA activity.

Determination of PA accumulation in thrombin-stimulated human platelets

The ${ }^{32} \mathrm{P}$-prelabeled platelet suspension $(4 \times$ $10^{8}$ cells $/ \mathrm{ml}, 0.4 \mathrm{ml}$ ) was preincubated with drug solution or vehicle at $37^{\circ} \mathrm{C}$ for $5 \mathrm{~min}$ and activated by the addition with $50 \mu l$ of $5 \mathrm{U} / \mathrm{ml}$ thrombin. After $20 \mathrm{sec}$ of incubation at $37^{\circ} \mathrm{C}$ under stirring $(1000 \mathrm{rpm})$, the reaction was stopped by adding $2 \mathrm{ml}$ of $\mathrm{CHCl}_{3} /$ methanol/ conc. $\mathrm{HCl}(20: 40: 1)$, and phospholipids were extracted and analyzed by the method of Tysnes et al. (21). The radioactivity in the PA fraction was measured as an index of PI turnover $(9,22)$.

\section{Measurement of intracellular $\left[\mathrm{Ca}^{2+}\right]\left(\left[\mathrm{Ca}^{2+}\right]\right)$ with fura2}

Loading of platelets with fura2 $(2 \mu \mathrm{M}$ was carried out as described by Rao et al. (23). After the cells had been washed free of excess dye, they were resuspended in $\mathrm{Ca}^{2+}$-free Tyrode solution containing $2 \mathrm{mM}$ EGTA (1.5 $\times 10^{8}$ platelets $/ \mathrm{ml}$ ). The fura2-loaded platelet suspension $(3 \mathrm{ml})$ was preincubated with or without drug $(3 \mu \mathrm{l})$ at $37^{\circ} \mathrm{C}$ for $10 \mathrm{~min}$; then thrombin was added at the final concentration of $0.05 \mathrm{U} / \mathrm{ml}$, and continuous fluorescence measurements were made in a Shimadzu RF. 540 spectrofluorometer. $\mathrm{Ca}^{2+}$ concentration was calculated by the procedure of Grynkiewicz et al. (24).

\section{0-K protein phosphorylation after stimulation} of platelets by thrombin

The mixture of $40 \mu \mathrm{l}$ of ${ }^{32} \mathrm{P}$-labeled platelets $\left(5 \times 10^{8}\right.$ cells $\left./ \mathrm{ml}\right)$ and $5 \mu \mathrm{l}$ of drug solution or vehicle was incubated at $37^{\circ} \mathrm{C}$ for $5 \mathrm{~min}$ and stimulated by $5 \mu \mathrm{l}$ of $5 \mathrm{U} / \mathrm{ml}$ thrombin. After $1 \mathrm{~min}$, the reaction was stopped by adding 25 $\mu \mathrm{l}$ of $2 \%$ SDS solution containing $63 \mathrm{mM}$ Tris, $10 \%$ glycerol, and $0.01 \%$ bromophenol blue ( $\mathrm{pH} 6.8$ ). The radioactive platelet proteins were analyzed by SDS-polyacrylamide slab gel electrophoresis under the conditions described by Laemmli (25). The gel was stained, dried on a filter paper and exposed to $\mathrm{X}$-ray film to prepare an autoradiograph, and the phosphorylation of protein with a molecular weight of about $40 \mathrm{~K}$ was determined according to the established method (7). The degree of phosphorylation was considered to reflect the PKC activity (7). 
Measurement of PDE and cyclic AMP content in platelets

Washed human platelets $\left(3-5 \times 10^{8}\right.$ cells/ml) suspended in $50 \mathrm{mM}$ Tris $/ \mathrm{HCl}$ (pH 7.5) were sonicated $(50 \mathrm{~W}, 30 \mathrm{sec})$ and ultracentrifuged for $60 \mathrm{~min}$ at $100,000 \times \mathrm{g}$. PDE activity was measured according to the method of Thompson and Strada (26), using the supernatant fraction described above as the enzyme preparation ( $10 \mu \mathrm{g}$ protein) and $\left[{ }^{3} \mathrm{H}\right]$ cyclic AMP as a substrate $(100,000 \mathrm{cpm})$ under the condition of $10 \mathrm{~min}$ incubation at $37^{\circ} \mathrm{C}$ with or without drug.

Platelet cyclic AMP was determined using a cyclic AMP radioimmunoassay kit (NEN, Boston, U.S.A.) based on a protein binding method, after incubation of $0.45 \mathrm{ml}$ of platelet suspension in Tyrode solution $\left(5 \times 10^{8}\right.$ cells $/ \mathrm{ml}$ ) with $0.05 \mathrm{ml}$ of drug solution or vehicle at $37^{\circ} \mathrm{C}$ for $3 \mathrm{~min}$.

\section{Measurement of $T X B_{2}$ production in platelets}

A mixture of $85 \mu \mathrm{l}$ of washed platelets $(5 \times$ $10^{8}$ cells $/ \mathrm{ml}$ ) suspended in $0.05 \mathrm{M}$ Tris $/ \mathrm{HCl}$ saline (pH 7.6) and $5 \mu \mathrm{l}$ of drug solution or vehicle was preincubated at $37^{\circ} \mathrm{C}$ for $5 \mathrm{~min}$. The reaction was started by the addition of 10 $\mu 1$ of $200 \mu \mathrm{M}\left[{ }^{14} \mathrm{C}\right] \mathrm{AA}(0.2 \mu \mathrm{Ci})$ and terminated by adding $300 \mu \mathrm{l}$ of stopping solution, consisting of ethylacetate/methanol/1 M citric acid (30:4:1), after $1 \mathrm{~min}$. The reaction mixture was dried over $0.5 \mathrm{~g}$ of $\mathrm{Na}_{2} \mathrm{SO}_{3}$ and centrifuged $(1,100 \times g, 5 \mathrm{~min})$. An aliquot of the supernatant solution $(50 \mu 1)$ was analyzed by thin layer chromatography according to the same method described above, and the radioactivity in $\mathrm{TXB}_{2}$ was determined.

\section{Measurement of $\mathrm{CO}$ activity}

SSVM were prepared by the method of Wallach and Daniels (27). The lyophilized microsomes wère used as the $\mathrm{CO}$ preparation after being dissolved in $0.1 \mathrm{M}$ Tris/ $\mathrm{HCl}$ buffer (pH 7.4) containing $5 \mathrm{mM}$ tryptophan and 5 $\mathrm{mM}$ glutathione. The enzyme solution $(0.2$ $\mathrm{mg} / \mathrm{ml}$ ) with or without drug ( $90 \mu \mathrm{l}$ in total) was preincubated at $25^{\circ} \mathrm{C}$ for $10 \mathrm{~min}$. The enzyme reaction was initiated by adding $10 \mu 1$ of
$0.2 \mathrm{mM}$ AA and stopped by adding $0.9 \mathrm{ml}$ of ethanol/1 M citric acid (180:1) $20 \mathrm{~min}$ later. The mixture was centrifuged $(2,000 \times g, 2$ min) and $P E_{2}$ content in the supernatant was assayed by using a $\mathrm{PGE}_{2}$ radioimmunoassay kit (NEN, Boston, U.S.A.) as an index of $\mathrm{CO}$ activity.

\section{Statistics}

Statistical significance was evaluated by Student's $t$-test. IC $_{50}$ values were calculated by Lichfield-Wilcoxon's method.

\section{RESULTS}

Effect on thrombin-induced platelet aggregation ASA alone did not inhibit this aggregation up to $500 \mu \mathrm{M}$, although it completely suppressed AA-induced platelet aggregation at $100 \mu \mathrm{M}$ (data not shown), which suggested that the $\mathrm{CO}$ activity in platelets was entirely inhibited under this condition. E5510 inhibited thrombin-induced platelet aggregation both in the presence and absence of $100 \mu \mathrm{M}$ ASA (Fig. 1). This indicates that E5510 inhib-

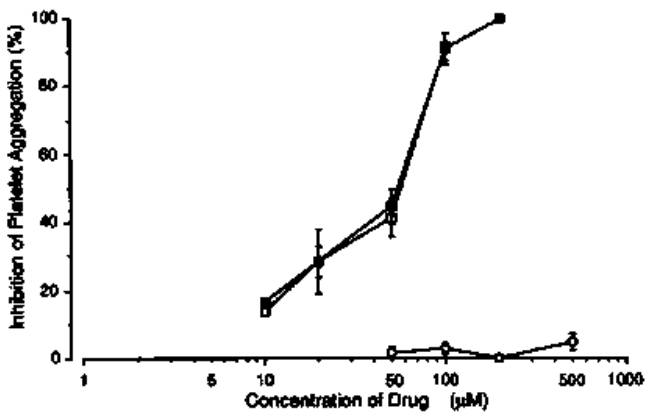

Fig. 1. Effects of E5510 on thrombin-induced platelet aggregation in aspirin-treated or untreated human washed platelets in vitro. Human washed platelet suspension was preincubated with $100 \mu \mathrm{M}$ aspirin or vehicle for $10 \mathrm{~min}$ at $37^{\circ} \mathrm{C}$. Platelet aggregation induced by $0.03 \mathrm{U} / \mathrm{ml}$ of thrombin was measured after $3 \mathrm{~min}$ of incubation with a desired concentration of E5510 solution, using both aspirin-treated and untreated human washed platelet suspensions. Each point represents the mean \pm S.E. of 2 or 3 preparations. ( $\square$ ); effect of E5510 in aspinin-treated platelets, ( $\square$ ): effect of E5510 in untreated platelets, (O): effect of aspirin in untreated platelets. 
its thrombin-induced platelet activation through a mechanism other than $\mathrm{CO}$ inhibition.

\section{Effects on platelet signal transduction in a} whole-cell system

As human platelets could be activated by thrombin even if platelet $\mathrm{CO}$ was inhibited by ASA (Fig. 1), it was considered that thrombin can induce cellular responses of platelets through a receptor-coupled signal transduction pathway other than AA cascade in platelets. In order to clarify further the difference between E5510 and $\mathrm{CO}$ inhibitors, we examined the effect of E5510 on AA release from phospholipids in platelets prelabeled with $\left[{ }^{14} \mathrm{C}\right] \mathrm{AA}$ after thrombin-stimulation in the presence of $100 \mu \mathrm{M}$ BW755C. Under these conditions, BW755C completely inhibited both $\mathrm{CO}$ activity $\left(\mathrm{TXB}_{2}+\mathrm{HHT}\right.$ production) and lipoxygenase activity (12-HETE production), but AA release was not affected after thrombin-stimulation (Table 1). E5510 inhibited thrombininduced AA release in platelets in which $\mathrm{CO}$ and lipoxygenase were inhibited (Fig. 2). Mepacrine, a $\mathrm{PLA}_{2}$ inhibitor (28), and OPC13013, a PDE inhibitor (29), also showed inhibitory effects but U53059, a CO inhibitor, tended to enhance AA release rather than inhibiting it. These results led us to examine the effect of E5510 on the second messengers in platelets after the activation by thrombin.

Receptor-linked increase in PI turnover, which was determined by measuring the accumulation of PA in response to thrombin, and the intracellular mobilization of free $\mathrm{Ca}^{2+}$ in thrombin-stimulated platelets were inhibited by $\mathrm{E} 5510$ in a concentration-dependent manner (Figs. 3 and 4).

Phosphorylation of $40-\mathrm{K}$ protein in thrombin-stimulated platelets, which was considered as PKC activation after the transient increase of diacylglycerol formation and mobj-

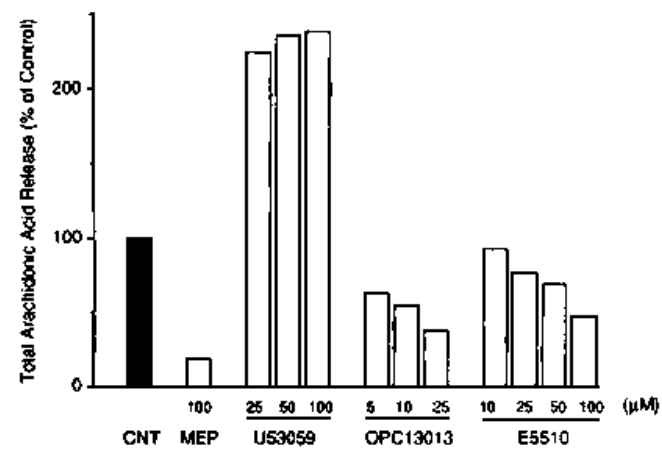

Fig. 2. Effects of E5510, U53059, mepacrine, and OPC13013 on arachidonic acid (AA) release from phospholipids in thrombin-stimulated human platelets in the presence of $\mathrm{BW} 755 \mathrm{C} .\left[{ }^{14} \mathrm{C}\right] \mathrm{AA}$-labeled platelet suspension containing $100 \mu \mathrm{M}$ BW755C was incubated for 3 min at $37^{\circ} \mathrm{C}$ with test drug solution at the desired concentration and stimulated by $0.05 \mathrm{U} / \mathrm{ml}$ of thrombin. Total AA release was measured by the same method described in Table 1. Results are the mean values of duplicate assays. CNT: control (vehicle instead of drug solution), MEP: mepacrine.

Table 1. Effect of BW755C on arachidonic acid release from phospholipids in thrombin-stimulated human platelets

\begin{tabular}{lccccc}
\hline & Thrombin & $\begin{array}{c}\mathrm{TXB}_{2} \\
+ \\
\text { HHT }\end{array}$ & 12-HETE & AA & $\begin{array}{c}\text { Total } \\
\text { AA } \\
\text { release }\end{array}$ \\
\hline Basal & - & 268 & 245 & 497 & 1011 \\
Control & + & 407 & 975 & 2429 & 3811 \\
BW755C & + & 254 & 179 & 3109 & 3524 \\
\hline
\end{tabular}

The figures in the table show the radioactivity in dpm. Human platelets $\left(3 \times 10^{8}\right.$ cells/tube) labeled with $\left[{ }^{14} \mathrm{C}\right]$-arachidonic acid were incubated with, or without 100 $\mu \mathrm{M} \mathrm{BW755C}$ for $3 \mathrm{~min}$ at $37^{\circ} \mathrm{C}$ and stimulated by $0.05 \mathrm{U} / \mathrm{ml}$ of thrombin. $\mathrm{TXB}_{2}$; thromboxane $B_{2}$, HHT: 12-hydroxy-5,8,10-heptadecatrienoic acid, 12-HETE: 12hydroxy-5,8,10,14-eicosatetraenoic acid, AA: arachidonic acid. Total AA release was calculated as the sum of the radioactivity in $\mathrm{TXB}_{2}+\mathrm{HHT}, 12-\mathrm{HETE}$ and AA. 


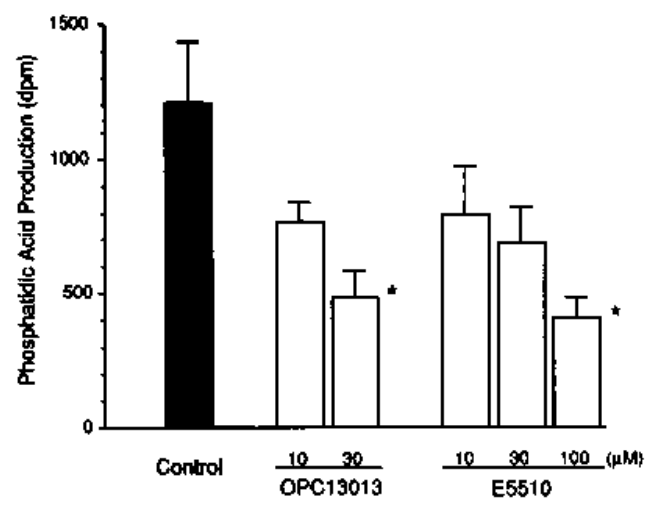

Fig. 3. Effects of E5510 and OPC13013 on phosphatidic acid production in thrombin-stimulated human ${ }^{32} \mathrm{P}$-prelabeled platelets. ${ }^{32} \mathrm{P}$-Labeled platelets $\left(4 \times 10^{8}\right.$ cells $/ \mathrm{ml}$ ) were incubated with or without drug for 5 $\min$ at $37^{\circ} \mathrm{C}$ and stimulated by $0.5 \mathrm{U} / \mathrm{ml}$ of thrombin for $20 \mathrm{sec}$. Phospholipids were extracted and separated by thin layer chromatography as described in Materials and Methods. The radioactivity in the phosphatidic acid spot was determined. Each column represents the mean \pm S.E. of triplicate assays. Asterisks indicate statistically significant differences compared to the control $(P<0.05)$.

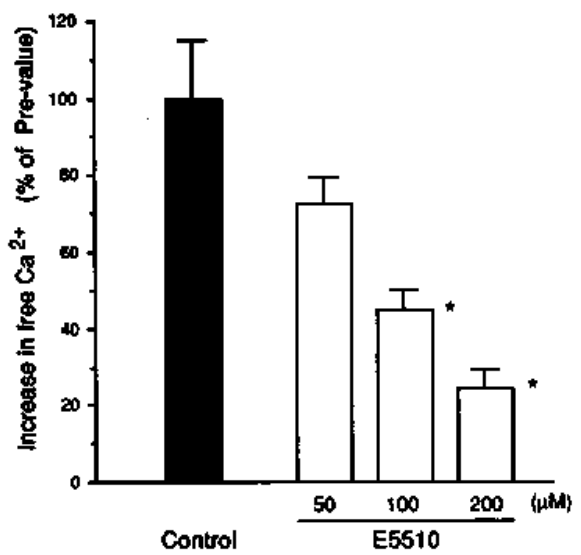

Fig. 4. Effects of E5510 on mobilization of $\left[\mathrm{Ca}^{2+}\right]_{i}$ in fura2-loaded human platelets after thrombin stimulation. After the fura2-loaded platelet suspension (1.5 $\times$ $10^{8}$ cells $/ \mathrm{ml}$ ) was preincubated with or without drug for $10 \mathrm{~min}$ at $37^{\circ} \mathrm{C}$, the platelets were stimulated by $0.05 \mathrm{U} / \mathrm{ml}$ of thrombin. The maximum $\left[\mathrm{Ca}^{2+}\right]_{\mathrm{t}}$ increase was measured from continuous fluorescence records and calculated as described in Materials and Methods. Each column represents the mean \pm S.E. of 8-14 experiments. Asterisks indicate statistically significant differences compared to the control $(P<0.05)$.

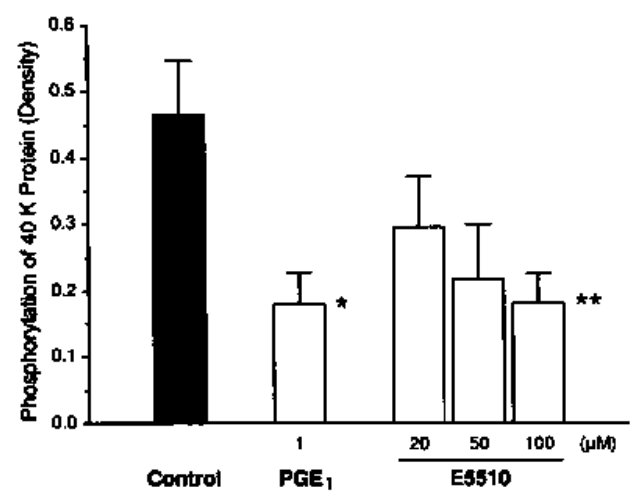

Fig. 5. Effects of E5510 and $\mathrm{PGE}_{1}$ on phosphorylation of $40-\mathrm{K}$ protein in ${ }^{32} \mathrm{P}$-labeled human platelets after thrombin stimulation. ${ }^{32} \mathrm{P}$-Labeled platelets $(5 \times$ $10^{\mathrm{B}}$ cells $/ \mathrm{ml}$ ) were incubated with or without drug for $5 \mathrm{~min}$ at $37^{\circ} \mathrm{C}$ and stimulated by $0.5 \mathrm{U} / \mathrm{ml}$ thrombin for $1 \mathrm{~min}$. The radioactive proteins were separated by sodium dodecyl sulfate-polyacrylamide slab gel electrophoresis, and phosphorylation of the protein with a molecular weight of about $40 \mathrm{~K}$ was measured as described in Materials and Methods. Each column represents the mean \pm S.E. of 5-7 experiments. Asterisks indicate statistically significant differences compared to the control $\left(^{* *}: \mathrm{P}<0.01 *: \mathrm{P}<0.05\right)$.

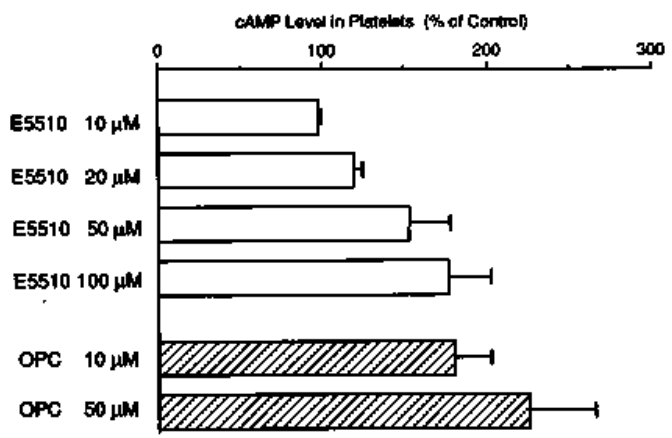

Fig. 6. Effects of E5510 and OPC13013 on cyclic AMP level in human platelets. Washed platelets $(5 \times$ $10^{8}$ cells $/ \mathrm{ml}$ ) were incubated with or without drug for $3 \mathrm{~min}$ at $37^{\circ} \mathrm{C}$ and cyclic AMP content was determined by radioimmunoassay. Cyclic AMP level in the control was $2.8 \pm 0.5 \mathrm{pmol} / 10^{8}$ platelets. Each column represents the mean \pm S.E. of 3-5 experiments. 
lization of $\left[\mathrm{Ca}^{2+}\right]_{i}(7)$, was inhibited by $\mathrm{E} 5510$ and $\mathrm{PGE}_{1}$ (Fig. 5).

In order to demonstrate the effect of E5510 on the negative signal transduction in platelets, cyclic AMP content in platelets was determined after incubation of the drug with washed platelet suspension (Fig. 6). E5510 caused a dose-dependent increase in platelet cyclic AMP level.

It was reported that platelet $\mathrm{CO}$ products (PG endoperoxide, TXA $\mathrm{A}_{2}$ ), synthesized from AA which is released from phospholipids by $\mathrm{PLA}_{2}$ and PLC after receptor-mediated platelet activation, could act as positive feedback promoters within the same platelets and activate PLC in other platelets $(14,30)$. Therefore, we examined the effect of E5510 on $\mathrm{TXA}_{2}$ production after the stimulation of platelets by AA in a whole-cell system. E5510 strongly and dose-dependently inhibited $\mathrm{TXB}_{2}$ (the stable metabolite of $\mathrm{TXA}_{2}$ ) production at extremely low concentrations, giving an $\mathrm{IC}_{50}$ value of $0.03 \mu \mathrm{M}$ (Fig. 7). This inhibitory potency of E5510 was almost the same as that of U53059.

Effect on platelet signal transduction in a cellfree system

The direct action of E5510 on CO activity

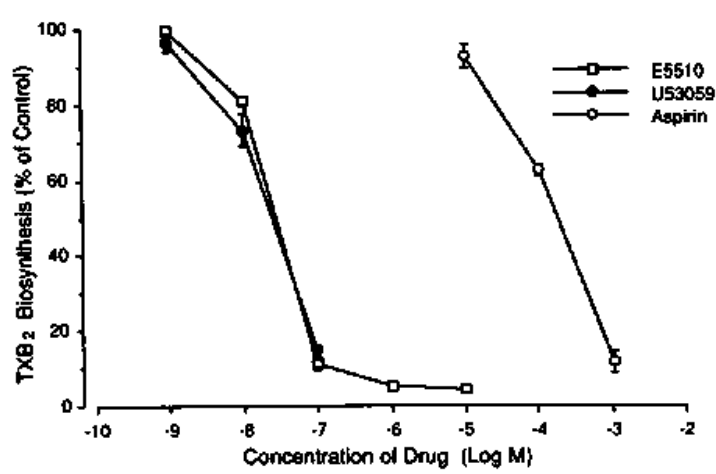

Fig. 7. Inhibitory effects of E5510, U53059 and aspirin on thromboxane $B_{2}\left(\mathrm{TXB}_{2}\right)$ biosynthesis in human platelets. Washed platelets $\left(5 \times 10^{8}\right.$ cells $\left./ \mathrm{ml}\right)$ were incubated with or without drug for $5 \mathrm{~min}$ at $37^{\circ} \mathrm{C}$ and $\left[{ }^{14} \mathrm{C}\right]$ arachidonic acid $(0.02 \mathrm{Ci} / 20 \mu \mathrm{M})$ was added. After 1 min, the reaction was stopped, and $\mathrm{TXB}_{2}$ was measured as described in Materials and Methods. was studied by determining the conversion of $A A$ to $\mathrm{PGE}_{2}$ by SSVM as the source of $\mathrm{CO}$. The $\mathrm{PGE}_{2}$ production rate in the control was $24 \mathrm{ng} \mathrm{PGE}_{2} / \mathrm{min} / \mathrm{mg}$ SSVM. Dose-dependent inhibition was seen with E5510 and U53059 (Fig. 8), and the $\mathrm{IC}_{50}$ values were $3 \mu \mathrm{M}$ and $0.03 \mu \mathrm{M}$, respectively. U53059 was 100 times more potent than E5510 in inhibiting $\mathrm{CO}$ activity. A PDE inhibitor, OPC13013, did not have any inhibitory effect on $\mathrm{CO}$ activity.

Cyclic AMP is well-known as a negative second messenger in platelets (12). The steady level of cyclic AMP in platelets is regulated by adenylate cyclase and PDE, the synthetic and degradative enzymes, respectively. We studied the effect of E5510 on these enzymes. E5510 did not modify the activity of adenylate cyclase (data not shown), but PDE activity (6 $\mathrm{pmol} / \mathrm{min} / \mathrm{mg}$ prot. in the control) was inhibited by $\mathrm{E} 5510$, giving an $\mathrm{IC}_{50}$ value of about $10 \mu \mathrm{M}$ (Fig. 9).

\section{DISCUSSION}

It was reported that $\mathrm{CO}$ inhibitors such as ASA and indomethacin are not able to inhibit thrombin-induced platelet activation (14). The thrombin-induced initial PLC activation in

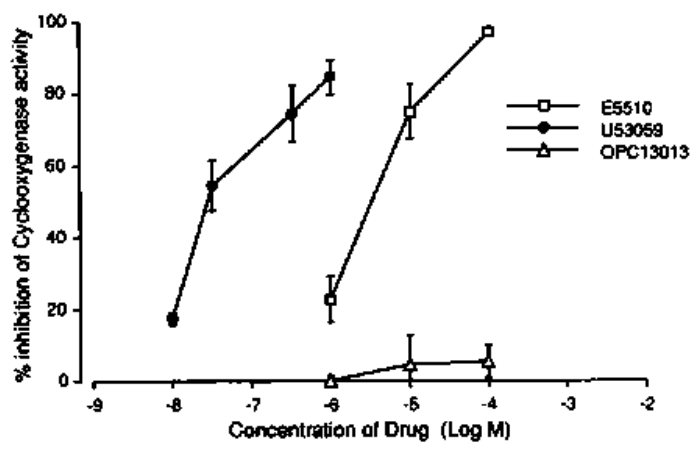

Fig. 8. Inhibitory effects of E5510, U53059 and OPC13013 on cyclooxygenase activity. Cyclooxygenase activity was measured using sheep seminal vesicular microsomes as the enzyme source and $20 \mu \mathrm{M}$ arachidonic acid as the substrate as described in Materials and Methods. $\mathrm{PGE}_{2}$ production was taken as a measure of cyclooxygenase activity. Results are expressed as $\%$ inhibition compared to the control, and each plot represents the mean \pm S.E. of $2-4$ experiments. 


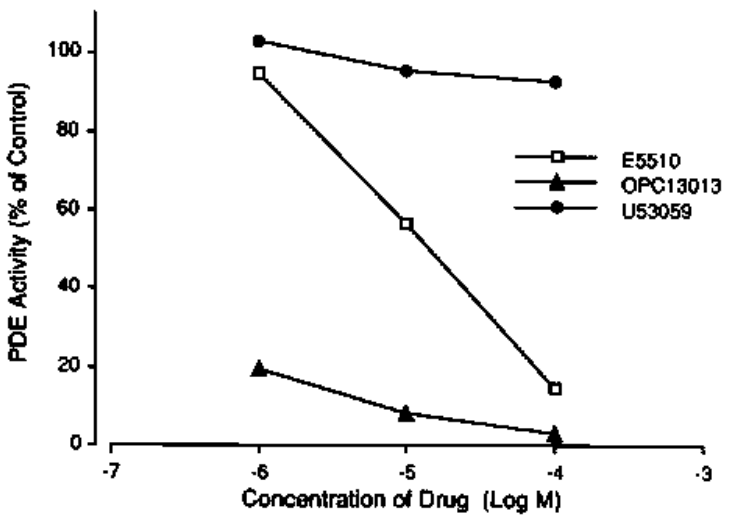

Flg. 9. Inhibitory effects of E5510, U53059 and OPC13013 on cyclic AMP-dependent phosphodiesterase (PDE). Phosphodiesterase activity was measured using human platelet cytosolic fraction as the enzyme source and $\left[{ }^{3} \mathrm{H}\right]$ cyclic AMP as the substrate, as described in Materials and Methods. Each plot represents the mean of duplicate assays.

platelets is dissociated from AA metabolism, as evidenced by inability of ASA to inhibit thrombin-stimulated production of diacylglycerol and PA production in platelets (14, 31). Our present finding that ASA did not inhibit thrombin-induced platelet aggregation is consistent with these reports, and we confirmed that E5510 clearly inhibited-thrombininduced platelet aggregation even in ASAtreated human platelets in which $\mathrm{CO}$ activity was completely suppressed. This strongly indicated that E5510 might have a different site of action from AA cascade in the process of receptor-mediated signal transduction in platelets. In order to clarify the mode of action of E5510 other than CO inhibition, we studied the effects of this compound on biochemical responses in the process of platelet signal transduction in a whole-cell system and a cell-free system.

In the whole-cell system, our previous report (1) showed that E5510 inhibited AA release from phospholipids after stimulation of platelets by thrombin, and it was found here that thrombin-stimulated AA release from platelet phospholipids was suppressed even under the condition of both $\mathrm{CO}$ and lipoxygenase inhibition by $\mathrm{BW} 755 \mathrm{C}$. This strongly in- dicated that E5510 influences second messengers of platelet signal transduction such as PI turnover, mobilization of $\left[\mathrm{Ca}^{2+}\right]_{i}$ and PKC activation, other than AA cascade. Actually, E5510 inhibited PA accumulation which could be considered as an index of initial PLC activation and acceleration of PI turnover in thrombin-stimulated platelets $(14,22)$, and it also inhibited thrombin-induced mobilization of $\left[\mathrm{Ca}^{2+}\right]_{i}$ in platelets. As the increase in $\left[\mathrm{Ca}^{2+}\right]_{i}$ results in the activation of PLA $\mathrm{A}_{2}$ (13), the inhibition of AA release from phospholipids is due to the suppression of mobilization of $\left[\mathrm{Ca}^{2+}\right]_{\mathrm{i}}$ which is caused by $\mathrm{IP}_{3}$ formation during the activation of PI turnover $(10,11)$. $\mathrm{PKC}$ activation, which was estimated by determining phosphorylation of $40-\mathrm{K}$ protein in thrombin-stimulated platelets, was inhibited by E5510 and $P G E_{1}$. Inhibition of PKC by $P E_{1}$ is reported to be due to cyclic AMP elevation in platelets by adenylate cyclase activation coupled with $\mathrm{PGE}_{1}$ receptor $(12,32)$, and the inhibition by $\mathbf{E 5 5 1 0}$ was supposed to be due to cyclic AMP elevation by PDE inhibition. These results suggested that E5510 antagonized thrombin-induced platelet activation by inhibiting receptor-mediated PLC activation and subsequent events in signal transduction, either directly or indirectly.

In the cell-free system, PDE activity in the cytosolic fraction of platelets was directly inhibited by E5510 in a dose-dependent manner. This result corresponded well with the fact that cyclic AMP level in platelets was dose-dependently elevated by E5510. It is well-established that the increased cyclic AMP level in platelets causes a decrease in cytosolic free $\mathrm{Ca}^{2+}$ by phosphorylating two microsomal proteins (24-K and $22-\mathrm{K}$ proteins), resulting in the enhancement of $\mathrm{Ca}^{2+}$-activated ATPase $(12,33,34)$. It was also reported that thrombin-mediated PLC activation is suppressed by the increased cyclic AMP in platelets $(15,35)$, probably acting at the G-protein level (36). These findings indicate that cyclic AMP can act as a negative messenger in the process of platelet activation (5). Therefore, it was concluded that the inhibition by E5510 of 
sequential steps of signal transduction such as PI turnover, mobilization of $\left[\mathrm{Ca}^{2+}\right]_{i}$, and PKC activation, was mediated by its increasing action on platelet cyclic AMP caused by the inhibition of PDE in thrombin-stimulated platelets.

In the cell-free system, E5510 also directly inhibited $\mathrm{CO}$ activity in a concentration-dependent manner. The $\mathrm{IC}_{50}$ value of $\mathrm{E} 5510$ in inhibiting $\mathrm{CO}$ was $3 \mu \mathrm{M}$ and that of U53059 was $0.03 \mu \mathrm{M}$. Our previous report (1) demonstrated that the $\mathrm{IC}_{50}$ values for inhibition of AA-induced platelet aggregation by E5510 and U53059 were 0.7 , and $0.03 \mu \mathrm{M}$, respectively. The potency of E5510 for the inhibition of the platelet aggregation was stronger than that for the inhibition of $\mathrm{CO}$ activity in the cell-free system, while the potencies of U53059 for inhibition of the platelet aggregation and $\mathrm{CO}$ activity were the same. These evidences are supported by the present findings that the activation of the $\mathrm{CO}$ pathway in the whole-cell system, which was measured in terms of $\mathbf{T X B}_{2}$ production, was very strongly inhibited by $\mathrm{E} 5510$ (IC $50: 0.03 \mu \mathrm{M}$ ), compared to its inhibition of $\mathrm{CO}$ activity in the cell-free system ( IC $_{50}: 3 \mu \mathrm{M}$ ). U53059, however, inhibited the $\mathrm{CO}$ pathway both in whole-cell and cell-free systems to the same extent. Consequently, it was suggested that this exaggerated inhibition in the whole-cell system by E5510 could be elucidated by its increasing action on platelet cyclic AMP in addition to the direct suppression of the $\mathrm{CO}$ pathway.

Overall, there was an indirect inhibition by E5510 of thrombin-mediated initial PLC activation, followed by $\mathrm{IP}_{3}$ and diacylglycerol formation, intracellular free $\mathrm{Ca}^{2+}$ mobilization leading to $\mathrm{PLA}_{2}$ activation and AA cascade promotion, and PKC activation. This indirect inhibition arose from cyclic AMP elevation in platelets through the direct suppression of PDE by E5510. The AA cascade, especially TXA $_{2}$ production, which can act as a powerful positive signal and feedback promoter of PLC resulting in acceleration of platelet activation, was strongly inhibited by E5510. Therefore, it was concluded that E5510 has multiple sites of action in receptor-mediated signal transduction: that is, $\mathrm{CO}$ inhibition and PDE inhibition. $\mathrm{CO}$ inhibition can reduce the positive signal transduction and PDE inhibition can promote the negative signal transduction in the biochemical responses of platelets. These multiple modes of action of E5510 synergistically operate in platelets to antagonize the cellular activation.

\section{REFERENCES}

1 Fujimori, T., Harada, K., Saeki, T., Kogushi, M., Akasaka, K., Yamagishi, Y. and Yamatsu, 1.: Pharmacological properties of the novel antiplatelet aggregating agent 4-cyano-5,5-bis (4-methoxyphenyl)-4-pentenoic acid. Arzneimittelforschung 37, 1143-1148 (1987)

2 Smith, J.B. and Willis, A.L.: Aspirin selectively inhibits prostaglandin production in human platelets. Nature New Biol. 231, 235 - 237 (1971)

3 Nishizawa, E.E., Mendoza, T., Honohan, T. and Annis, K.A.: A thiazole compound with potential antithrombotic activity. Thromb. Haemost. 47, $173-176$ (1982)

4 Nishizuka, Y.: The role of protein kinase $\mathrm{C}$ in cell surface signal transduction and tumor promotion. Nature 308, 693-698 (1984)

5 Haslam, R.J.: Signal transduction and platelet activation. In Thrombosis and Haemostasis, Edited by Verstraete, M., Vermylen, J., Lijnen, H.R. and Arnout, J., p. 147-172, Leuven University Press, Leuven (1987)

6 Rittenhouse-Simmons, S.: Production of diglyceride from phosphatidylinositol in activated human platelets. J. Clin. Invest. 63, 580-587 (1979)

7 Kawahara, Y., Takaj, Y., Minakuchi, R., Sano, K. and Nishizuka, Y.: Phospholipid turnover as a possible transmembrane signal for protein phosphorylation during human platelet activation by thrombin. Biochem. Biophys. Res. Commun. 97, $309-317$ (1980)

8 Wilson, D.B., Neufeld, E.J. and Majerus, W.: Phosphoinositide interconversion in thrombinstimulated human platelets. J. Biol. Chem. 260, 1046 - 1051 (1985)

9 Lloyd, J.V. and Mustard, J.F.: Changes in ${ }^{3 z} \mathrm{P}-$ content of phosphatidic acid and phosphoinositides of rabbit platelets during aggregation induced by collagen or thrombin. Br. J. Haematol. 26, 243253 (1974)

10 O'Rourke, F.A., Halenda, S.P., Zavoico, G.B. and Feinstein, M.B.: Inositol 1,4,5-trisphosphate 
releases $\mathrm{Ca}^{2+}$ from a $\mathrm{Ca}^{2+}$-transporting membrane vesicle fraction derived from human platelets. J. Biol. Chem. 260, 956-962 (1985)

11 Authi, K.S. and Crawford, N.: Inositol 1,4,5-trisphosphate induced release of sequestered $\mathrm{Ca}^{2+}$ from highly purified human platelet intracellular membranes. Biochem. J. 230, 247-253 (1985)

12 Takai, Y., Kikkawa, U., Kaibuchi, K. and Nishizuka, Y.: Membrane phospholipid metabolism and signal transduction for protein phosphorylation. Adv. Cyclic Nucleotide Prot. Phosphorylation Res. 18, $119-158$ (1984)

13 Loeb, L.A. and Gross, R.W.: Identification and purification of sheep platelet phospholipase $\mathrm{A}_{2}$ isoforms: Activation by physiologic concentration of calcium ion. J. Biol. Chem. 261, 10467-10470 (1986)

14 Lapetina, E.G.: The role of phospholipase $\mathrm{C}$ in platelet responses. Life Sci. 33, 1011-1018 (1983)

15 Watson, S.P., McConnell, R.T. and Lapetina, E.G.: the rapid formation of inositol phosphates in human platelets by thrombin is inhibited by prostacyclin. J. Biol. Chem. 259, 13199 - 13202 (1984)

16 Born, G.V.R. and Cross, M.J.: The aggregation of blood platelets. J. Physiol. (Lond.) 168. 178$195(1963)$

17 Haslam, R.J. and Lynham, J.A.: Relationship between phosphorylation of blood platelet proteins and secretion of platelet granule constituents: $I$. Effect of different aggregating agents. Biochem. Biophys. Res. Commun. 77, 714-722 (1977)

18 Smith, J.B., Dangelmaier, C. and Mauco, G.: Measurement of arachidonic acid liberation in thrombin-stimulated human platelets: Use of agents that inhibit both the cyclooxygenase and lipoxygenase. Biochem. Biophys. Acta 835, 344351 (1985)

19 Bligh, E.G. and Dyer, W.J.: A rapid method of tetal lipid extraction and purification. Can. J. Biochem. Physiol. 37, 911-919 (1959)

20 Salmon, J.A. and Flower, R.J.: Extraction and thin-layer chromatography of arachidonic acid metabolites. Methods Enzymol. 86, 477-493 (1982)

21 Tysnes, O.-B., Verhoeven, A.J.M. and Holmsen, H.: Phosphate turnover of phosphatidylinositol in resting and thrombin-stimulated platelets. Biochem. Biophys. Acta 889, $183-191$ (1986)

22 Siess, W., Siegel, F.L. and Lapetina, E.G.: Arachidonic acid stimulates the formation of 1,2 diacylglycerol and phosphatidic acid in human platelets. J. Biol. Chem. 258, 11236-11242 (1983)

23 Rao, G.H.R., Peller, J.D. and White, J.G.: Measurement of ionized calcium in blood platelets with a new generation calcium indicator. Biochem. Biophys. Res. Commun. 132, 652-657 (1985)

24 Grynkiewicz, G., Poenie, M. and Tsien, R.Y.: A new generation of $\mathrm{Ca}^{2+}$ indicators with greatly improved fluorescence properties. J. Biol. Chem. $260,3440-3450$ (1985)

25 Laemmli, U.K.: Cleavage of structural proteins during the assembly of the head of bacteriophage T4. Nature 227, 680-685 (1970)

26 Thompson, W.J. and Strada, S.J.: Cyclic nucleotide phosphodiesterase (PDE). Methods Enzymat. Anal, 4, 127-134 (1984)

27 Wallach, D.P. and Daniels, E.G.: Properties of a novel preparation of prostaglandin synthetase from sheep seminal vesicles. Biochem. Biophys. Acta 231, 445-457 (1971)

28 Hofman, S.L., Prescott, S.M. and Majerus, P.W.: The effects of mepacrine and p-bromophenacyl bromide on arachidonic acid release in human platelets. Arch. Biochem. Biophys. 215, 237-244 (1982)

29 Umekawa, H., Tanaka, T., Kimura, Y. and Hidaka, H.: Purification of cyclic adenosine monophosphate phosphodiesterase from human platelets using new-inhibitor Sepharose chromatography. Biochem. Pharmacol. 33, 3339-3344 (1984)

30 Siess, W., Cuatrecasas, P. and Lapetina, E.G.: A role for cyclooxygenase products in the formation of phosphatidic acid in stimulated human platelets. J. Biol. Chem. 258, 4683-4686 (1983)

31 Siess, W., Weber, P.C. and Lapetina, E.G.: Activation of phospholipase $\mathrm{C}$ is dissociated from arachidonate metabolism during platelet shape change induced by thrombin or platelet-activating factor. J. Biol. Chem. 259, 8286-8292 (1984)

32 Schafer, A.I., Cooper, B., O'Hara, D. and Handin, R.I.: Identification of platelet receptors for prostaglandin $I_{2}$ and $D_{2}$. J. Biol. Chem. 254, 2914 -2917 (1979)

33 Kaser-Glanzmann, R., Gerber, E. and Luscher, E.F.: Regulation of the intracellular calcium level in human blood platelets: cyclic adenosine $3^{\prime}, 5^{\prime}$ monophosphate dependent phosphorylation of a 22,000 dalton component in isolated $\mathrm{Ca}^{2+}$-accumulating vesicles. Biochem. Biophys. Acta 558, 344347 (1979)

34 Katz, A.M., Tada, M. and Kirchberger, M.A.: Control of calcium transport in the myocardium by the cyclic AMP-protein kinase system. Adv. Cyclic Nucleotide Res. 5, 453-472 (1980)

35 Imai, A., Hattori, H., Takahashi, M. and Nozawa, Y.: Evidence that cyclic AMP may regulate $\mathrm{Ca}^{2+}$-mobilization and phospholipases in thrombin-stimulated human platelets. Biochem. 
Biophys. Res. Commun. 112, 693-700 (1983)

36 Halenda, S.P., Volpi, M., Zavoico, G.B., Sha'afi, R.I. and Feinstein, M.B.: Effects of thrombin, phorbol myristate acetate and prostaglandin $D_{2}$ on
$40-41 \mathrm{kDa}$ protein that is ADP ribosylated by pertussis toxin in platelets. FEBS Lett. 204, 341346 (1986) 